\title{
IAMJ
}

INTERNATIONAL

AYURVEDIC

MEDICAL JOURNAL

ISSN: 23205091

Impact Factor: 6.719

\section{MANAGEMENT OF GRANTHIBHUTA AARTAVA DUSHTI W.S.R. TO PCOD- A CASE REPORT}

\author{
Shruti R. Tarapure', Tushar Anil Annadate², Hinaben Harshadkumar Shah ${ }^{3}$ \\ ${ }^{1}$ Assistant Professor, Dept. of Kayachikitsa, \\ ${ }^{2}$ P.G. Scholar, Dept. of Prasutitantra \& Streerog, \\ ${ }^{3}$ P.G. Scholar, Dept. of Kayachikitsa, \\ Seth Govindji Raoji Ayurved Mahavidyalaya, Solapur, Maharashtra, India
}

Corresponding Author: drtushonly24@gmail.com

\section{https://doi.org/10.46607/iamj13p5012020}

(Published online: November 2020)

Open Access

(C) International Ayurvedic Medical Journal, India 2020

Article Received: 17/11/2020 - Peer Reviewed: 16/11/2020 - Accepted for Publication: 22/11/2020

\section{Check for updates}

\begin{abstract}
Poly Cystic Ovarian Disease is a heterogeneous multisystem endocrinopathy in women of reproductive age with the ovarian expression of various metabolic disturbances and clinical features like hyperandrogenism, chronic anovulation, and obesity, resulting from insulin resistance and the compensatory hyperinsulinemia. Poly Cystic Ovarian Disease is a condition where cysts on the ovaries are present that prevent the ovaries from performing normally. On the basis of ultrasound evaluation there will be presence of peripherally tiny follicles. Clinically the PCOS can be understood based on assessment for Granthibhuta Aartava Dushti. (PCOS) can be correlated with Aartava Kshaya, Arajaska Yonivyapad, Lohitakshaya Yonivyapad, Shushka Yonivyapad and Shandhi Yonivyapad. PCOD affects 5-6 \% women in childbearing age and is increasing due to change in lifestyle and stress. It is also becoming the common problem in adolescents. So, the management of PCOD is very helpful when it is done by the way which doesn't affect other hormonal levels and without any further complications. In Ayurveda there are some medications and treatment protocols which are very helpful to manage the PCOS in such a way that doesn't affect the health of woman. Also, Ayurvedic management of PCOS gives relief in other features of disease like Obesity. So, here attempt has been made for the management of Granthibhuta Aartava Dushti w.s.r. to PCOD.
\end{abstract}


Keywords- Polycystic Ovaries, Infertility, Granthibhuta Aartava Dushti, Shodhana chikitsa, Shamana Chiktsa.

\section{INTRODUCTION}

Poly Cystic Ovarian Disease (PCOD) is the collection of signs and symptoms related to ovarian dysfunction. It was originally described by Stein and Leventhal in 1935, hence, also called as 'Stein-Leventhal Syndrome.' ${ }^{1}$ Poly Cystic Ovarian Disease (PCOD) is a highly prevalent endocrine metabolic disorder that points toward various severe consequences to female health associated with psychological impairments. PCOD affects $5-6 \%$ women in childbearing age and is increasing due to change in lifestyle and stress. ${ }^{2}$ The exact etiology of PCOD is not known although it is known to feature several hormonal disturbances including hyperandrogenism, Insulin resistance, Hyperinsulinemia, Obesity and Infertility. Among these, infertility is one of the most prone morbidity. Most women with PCOD are overweight, further enhancing androgen secretion while impairing metabolism and reproductive functions and possibly preferring the development of the PCOD phenotype. There is no defect in Hypothalamo-Pituitary-Ovarian axis, but normal function is guarded by inhibition of ovarian follicular development and inappropriate feedback to pituitary. The high estrogen production is mainly due to conversion of androgen into estrogen in the ovary. It leads to increase in luteinizing hormone (LH) and decrease in follicle stimulating hormone (FSH). An unkind circle is established for the increase in luteinizing hormone which induces thecal hyperplasia and increased androgen synthesis in the ovary. High level of androgen results in increase in the peripheral production of the sex hormone binding globulin (SHBG). This leads to increased level of free androgens to produce hirsutism and to be converted to estrogen. In normal women androgen production rate is the result of adrenal and ovarian secretion and conversion from precursors in peripheral tissues particularly the adipose tissue and skin. As the exact etiology is poorly understood, there is difference of opinion about diagnostic criteria and clinical features of the disease. The management of PCOD is challenging task, facing modern gynaecologists, so the holistic approach is required in the man- agement of PCOD. In Ayurveda this particular feminine disorder is not described in detail although some clinical features closely correlate with Granthibhuta Aartava Dushti.

Presentation of Case- A Patient aged 27 years, female, with marital history of $3 \frac{1}{2}$ year with trying period $3 \frac{1}{2}$ year with satisfactory sexual life complaining of no issues, Irregular menses since 3 years, anxious to conceive.

Associated Complaints- Patient had c/o Ushanadhikyata (Hotflushes), Mukhapaka, (Stomatitis) Netradaha, (Burning in eyes) Dourbalyata (General debility) since 6 months.

History of Present Illness- For the above complaints she consulted to various fertility specialist centers as well as she also consulted to gynecologists for irregular menstrual cycles, taken medicines for same upto 1 year \& 6 months. After that she got regular menstrual cycle for 3 to 4 months again after she started to complaints of same. Then she came to our hospital for complaint of no issue and taken treatment.

Past History- N/H/O- HTN \& DM, TORCH infection.

$\mathrm{H} / \mathrm{O}$-B/L PCOD since 3 years.

Drug History - taken modern medicine for PCOD up to 1year 6 month.

Gynac and Obs History- Nulligravida, M/H- Irregular menstrual cycle since 3 to 4 years associated with clots.

\section{Personal History-}

Ahara- Mixed, 3 Times a Day, Katu \& madhura rasa pradhana, Mala- Prakruta, once in a day

Mutra- 4 to 5 times/day, Clear, Yellowish in colour, Nidra- 8 hours at night.

H/O Diwaswapna (Day sleep) daily 1 hour since 6 to 7 years.

Ashtasthana Parikshana- Patient was examined with Ashtasthana parikshana. Her Nadi was 78 beats/min, mala was clear, once in a day, mutra was Prakruta, Jivha was Alpalipta, Shabda was Spashta 
Bhashana and Shravana, Druka was Prakruta, Sparsha was Ushana. Her Akruti was Madhyama.

General Examinations- Her Built and nourishment was moderate. Cyanosis was absent. Pallor, Icterus, Edema, Lymphadenopathy was absent. Gait and speech were normal.

Vitals- Her Temperature was 98.6F. Her Pulse was 78/min. Her Resp. Rate was 20 cycles /min. Her B.P was 120/90mmHg.

\section{Systemic Examinations-}

CNS- Conscious and oriented to time, place and person

CVS- S1 S2 normal, no added sounds

RS- Clear

$\mathrm{P} / \mathrm{A}$ - Soft, non-tender, no organomegaly

\section{Investigations-}

Thyroid profile- T3- $0.75 \mathrm{mg} / \mathrm{dl}, \mathrm{T} 4-9.03 \mathrm{mg} / \mathrm{dl}$, TSH- $6.57 \mathrm{UI} / \mathrm{ml}$

USG- B/L PCOD, done 6 months back.

Diagnosis- Vandhya (Infertile woman) with Granthibhuta Aartava Dushti [PCOD]

\section{Samprapti Ghataka-}

Dosha: Tridosha with Vata \& Kapha predominance, Dushya: Rasa \& Rakta, Agni: Dhatavaagni, Jatharagni., Ama: Dhatwagni Mandhya Janya, Jatharagni., Strotas: Artava Vaha according to Sushruta Phalavaha, Strotodushti: Sangha \& Vimargagamana., Udbhavasthana: Amashaya., Adhishthana: Garbhashaya., Vyadhi Swabhava: Chirakari, Sadhyasadhyata: Krichhra Sadhya, Vyadhi Marga: Baahya Roga Marga

Therapeutic Intervention- Present case study was single case study. Shodhana (Purification) followed by shaman chikitsa (Alleviation) administrated was done in following manner- Dipana, Pachana, Snehapana, Virechana (Purgation) details given in table no. 02. Details of Shamana Chikitsa like chronological intervention, duration of treatment, medicines used, doses etc. have been enlisted in table no. 01 Dipana, Pachana, Snehapana, Vamana (Emesis) details given in table no. 03

\section{DISCUSSION}

In this Present study, the commencement of treatment was done by Ampachana with Arogyavardhini Vati. Kashyapa stated that infertility gets cured by use of virechana. ${ }^{3}$ While giving the Virechana, Snehapana was done with Phalaghruta. Phalaghruta is the most recommended formulation in the treatment of infertility and recurrent abortions., ${ }^{4,6,}$, For abhyanga, Ksheerabala Taila was used because it normalizes the channels (Strotas) followed by Bashpa Sweda. Virechana was done with Trivrut leha. Virechana Karma has direct effect on Agnisthana (hampered Ag$n i$ is one of the initiating factors in Rajodushti). It pacifies the vitiated Kapha and Vatadosha and removes vitiated excessive Pitta \& thus do Raktashodhan. It does the Strotovishodhana Karma also After that Kalyanakaghruta, Saraswatarishta, Tab. Pushpadhanva rasa was given. Most of the ingredients of Pushpadhanva rasa have Tridosha Nashaka properties which act primarily in Samprapti Vighatana of PCOD. Pushpadhanva rasa is Vata Niyamaka and Pitta Kapha Shamaka which helps in Bijotpatti and Bijotsarga. ${ }^{7}$ All medicines were given for 1 month. In the next follow up Patient advised with Tab. Rajapravartini Vati, Shatpushpa Churna, Nagkeshar Churna, Ashokarista- Ashokarishta may act as hrudya, balya, rejuvenates and strengthen body. This is used to enhance endometrial receptivity to avoid recurrent abortion. ${ }^{8,9}$ Shatapushpa Churna has the properties like Madhura, Kashaya, Snigdha, Vrushya and Bruhana, these properties increase Bala of patient. It acts as Yonishodhana, Artava Janaka, Shatavari is said to be Putra Pradayini, and Pushpa Utpanna Kari, Rutu Pravartini. Shatavari is Vata Prashamani. With all this actions Shatavari might corrects Artava Kshaya and cause normalcy in menstrual cycle. Shatapushpa is a phytoestrogen; it exerts both estrogenic and anti-estrogenic activity depending on the condition. It acts in both high estrogenic and low estrogenic condition ${ }^{10}$

Raja Pravartini Vati ${ }^{11}$ has direct action on the Artava Vaha Strotas. The ingredients are having Katu Rasa, Katu Vipaka, Laghu, Rooksha, Tikshna Guna, Ushna Veerya, Vata Kapha Hara and Pitta Vardhaka proper- 
ties All these properties remove the obstruction in the passage and does Strotoshodhana.

The main action of Vamaka Dravya is on Amashaya of the individual. In the Amashaya it acts on the very root cause of the vitiation of Kapha. The vitiated Kapha present in entire body is expelled out through the mechanism of Vamana and intensity of the pathogenesis is controlled to the maximum level. Dipana and Pachana was done by Agnitundi Vati before the Vamana Chikitsa. Snehapana was done with Kalyanaka Ghrut. Majority of the drugs of Kalyanakaghruta are having Tridoshashamaka, Dipana, Pachana, Vrishya, Rasayana, Yonidoshahara, Garbhasthapaka properties. According to modern science, Ghruta is lipophilic in nature, thus it diffuses rapidly across the cell membrane which is also composed of bimolecular lipid matrix and Ghruta can also cross blood brain barrier and acts on central nervous system i.e. hypothalamus and pituitary gland and may correct hormonal imbalance. Ghruta contains the cholesterol which is responsible for the synthesis of steroid hormones i.e. estrogen and progesterone.

As per the mode of action of Vamana Karma, it clears the channels (Strotas) from the Sanga, created by vitiated Kapha, Meda and Ama. Maximum Doshas are thrown out from the body by this process, thus detoxifying the body up to a certain level. The remnant Doshas are controlled by Shamana therapy which includes Rakta Prasadana, Kapha-Vatahara, Artava Janana, Rutu Pravartini properties. Sukumar Kashaya is made of 27 medicinal plants. It's having antioxidant potential. ${ }^{12}$ Vandhyatva (Infertility) has not been described as a separate entity in Ayurvedic classics, but all the gynecological disorders are undertaken as twenty Yonivyapad as. The Yoni never gets diseased without vitiated Vata. ${ }^{13}$ Hence, Dashamula Kashaya was used because it possesses the Vata Shamaka property. Garbhapala Rasa has the property of garbhasthapaka hence it was used to avoid the pregnancy loss. Shatavari nourishes the endometrium and prepares the reproductive organs for conception and prevents threatened abortion. Shatavari contains precursor of estrogen i.e. phytoestrogens, which increases amount of cervical mucus and motility of sperms in cervical mucus. ${ }^{14}$ After Shodhana Karma Shaman Chikitsa helps to correct the Rutu, Kshetra, Ambu and Bija which are basic requirements for reproduction. They also help the patient in correcting her Aartava Dushti and Agneya Guna of Aartava. Therefore, patient conceived in approximately in less than one year of treatment.

Diet and Fertility- As per modern view diet should not be severely deficit in micronutrients, folic acid, zinc or antioxidant so as to affect the ovarian function or the spermatogenesis but in Ayurveda the importance of diet is not merely limited to provide nourishment it is also responsible for all the changes in the body. By the use of Ghruta \& Ksheera in diet the fertility period may be prolonged.

\section{CONCLUSION}

PCOD is an emerging problem among women of reproductive age group leading to infertility $\&$ multiple signs \& symptoms. The condition is to be properly perceived, interpreted $\&$ diagnosed before providing a better line of treatment. It is the need of the hour to contribute a comprehension care through Ayurveda which should be complete the patient.

\section{REFERENCES}

1. Howkins and Bourne, Shaw's Textbook of Gynecology, Edited by V.G. Padubidri, Shirish. N. Daftary chapter no 32, Disorders of the ovary B. I. Churchill Livingstone Pvt Ltd, New Delhi $16^{\text {th }}$ Edition pg. no. 429.

2. Howkins and Bourne, Shaw's Textbook of Gynecology, Edited by V.G. Padubidri, Shirish. N. Daftary chapter no 32, Disorders of the ovary B. I. Churchill Livingstone Pvt Ltd, New Delhi $16^{\text {th }}$ Edition pg. no. 429.

3. Tiwari P. Kashypa Samhita, Shiddhisthana, Panchkarmiyasiddhi Verse 7/5, Edition and Translation, Chaukhambha Sanskrit Pratisthan; Varanasi; 1996.pg.no.166 [Google Scholar] [Ref list]

4. Gupta A. Astang Sangraha, Hindi Commentary, Uttarasthana, Guhyarogapratishedhiyam Verse 39/81. Nirnaya Sagar Press; Varanasi: 1951.pg.no.340[Google Scholar]

5. Tripathi B. Ashtanga Hridaya, Nirmala Hindi Commentary, Uttarasthana Guhyarogapratishedhiyam Verses 34/63-67. Vol. 2. Chaukhambha Sanskrit Pratisthan; Varanasi: 2003. pg.no 772 [Google Scholar] 
6. Mishra BS. Bhawaprakash, Vidyotini Hindi Commentary, Chikitsasthana Verses 70/54-56, 58-59. Part 2. Choukhambha Sanskrit Series; Varanasi:1964.page.no 808 [Google Scholar]

7. Dhanashri Deshpande, et al; A review on pushpadhanva rasa in vandhyatva (Anovulatory Factor of Infertility), World Journal Of Pharmaceutical And Life Science, 2019, vol.5, Issue 8, 221-224.

8. Anonymous. Ayurvedic Formulary of India, Part- I, Part A, 1:5 Ashokarishta (Bhaishajyaratnavali Strirogadhikara) 2nd ed. New Delhi: Department of AYUSH, Ministry of Health and Family Welfare, Government of India; 2003. pg.no 8. [Google Scholar]

9. Anonymous. Ayurvedic Pharmacopoeia of India. Reprint. Part-I. 1st ed. Vol. 1. New Delhi: Department of AYUSH, Ministry of Health and Family Welfare, Government of India; 2001. pp. 19-20. [Google Scholar]

10. Santhosha, D., Ramesh, A., Prasad, M. S., \& Dhanalakshmi, C. H. Research Journal of Pharmaceutical, Biological and Chemical Sciences. 2011; 2(4): 427
11. Dr. Bhagyalakshmi B.R, A Pharmaceutico-Analytical and Experimental study of Rajapravartini vati w.s.r. to its action on uterus, Dissertation submitted to the Rajiv Gandhi University of Health science, Bengaluru ,201112

12. Antioxidant study of one Ayurvedic Medicine, "Sukumara Kashayam”. Int. J. Pharm. Sci. Rev. Res., 42(1), January - February 2017; Article No. 06, Pages: 35-41, https://www.researchgate.net/publication/313160026

13. Pt. Kashinath Shastri, Dr, Gorakhnath Chaturvedi, Charak Samhita Chikitsa Sthan Yonivyapadchikitsaadhyaya 30/115, Vidyotani Hindi commentary Chaukhamba Bharati Academy Varanasi, 2009 page.no. 770

14. Bopana N, Saxena S. (2007) Asparagus racemosus Ethnopharmacological evaluation and conservation needs. J Ethnopharmacol; 110:1-15

Table 1 Treatment Protocol.

\begin{tabular}{|c|c|c|c|}
\hline Date & Shaman Chikitsa & Matra/Duration & Shodhan Chikitsa \\
\hline $\begin{array}{l}22 / 11 / 14 \\
02 / 12 / 14\end{array}$ & Amapachan with Arogyavardhani vati & 1 BD for 10 days. & \\
\hline $\begin{array}{l}05 / 12 / 14 \\
12 / 12 / 14\end{array}$ & & & $\begin{array}{l}\text { Virechana (Detail } \\
\text { in Tab.no.02) }\end{array}$ \\
\hline \multirow{3}{*}{$\begin{array}{l}\text { 16/12/14 } \\
(\text { L.M.P = 29/11/14) }\end{array}$} & Kalyanak Ghrita & 1 tsf BD with milk before food & \\
\hline & Saraswatarista & 3 tsf BD with water after food. & \\
\hline & $\begin{array}{l}\text { Tab. Pushpadhanva rasa } \\
\text { (Day 1-Day 15) }\end{array}$ & $1 \mathrm{BD}$ with water after food. & \\
\hline \multirow[b]{3}{*}{$\begin{array}{l}\text { 20/02/15 } \\
(\text { L.M.P = 30/12/14) }\end{array}$} & Tab. Rajapravartani vati & $1 \mathrm{BD}$ with water after food. & \\
\hline & Shatapushpa churna + nagkesar churna & 1 tsf BD with water after food. & \\
\hline & Ashokarista & $10 \mathrm{ml} \mathrm{BD}$ with water after food. & \\
\hline $20 / 03 / 15$ & Amapachan with Agnitundi Vati & $1 \mathrm{BD}$ after food for 2 days. & \\
\hline $23 / 03 / 15-27 / 03 / 15$ & & & $\begin{array}{l}\text { Vaman (Detail in } \\
\text { Tab. No.03) }\end{array}$ \\
\hline \multirow{3}{*}{$\begin{array}{l}30 / 03 / 15 \\
(\text { L.M.P }=08 / 03 / 15)\end{array}$} & Tab.Rajapravartani vati & $1 \mathrm{BD}$ with water after food. & \\
\hline & Satapushpa churna & 1 tsf BD with water after food. & \\
\hline & Sukumar kashaya & 3 tsf BD with water after food. & \\
\hline \multirow{5}{*}{$\begin{array}{l}13 / 04 / 2015 \\
(\text { L.M.P }=13 / 04 / 15)\end{array}$} & Tab. Pushpadhanva rasa (Day 1-Day 15) & $1 \mathrm{BD}$ with water after food. & \\
\hline & Dashmoolkashaya & 3 tsf BD with water after food. & \\
\hline & Kumaryasav & 3 tsf BD with water after food. & \\
\hline & $\begin{array}{l}\text { Shatavari churna }+ \text { Amrutasatva }+ \\
\text { Amalki churna. }\end{array}$ & $1 / 2$ tsf with water after food. & \\
\hline & Natural Intercourse & & \\
\hline
\end{tabular}




\begin{tabular}{|c|c|c|}
\hline $\begin{array}{l}25 / 05 / 15 \\
(\text { L.M.P }=26 / 05 / 15) \\
\text { Cycle - Delayed } \\
\text { for } 15 \text { days. }\end{array}$ & Tab. Gynova & $1 \mathrm{BD}$ with water after food. \\
\hline $\begin{array}{l}02 / 07 / 15 \\
(\text { L.M.P }=01 / 07 / 15)\end{array}$ & Tab.Garbhapala rasa & $\begin{array}{l}1 \mathrm{BD} \text { with water after food for } 15 \\
\text { days. }\end{array}$ \\
\hline $27 / 08 / 15$ & $\begin{array}{l}\text { clo-Amenorrhea } \\
\text { Nausea \& Vomiting. } \\
\text { UPT- Positive. }\end{array}$ & \\
\hline
\end{tabular}

Table 2: Details of Virechana Karma

\begin{tabular}{|c|c|c|c|c|c|c|c|c|}
\hline Date & \multicolumn{2}{|l|}{ Procedure } & \multicolumn{4}{|c|}{ Drug \& Dosage } & \multicolumn{2}{|c|}{ Duration } \\
\hline $23 / 11 / 14$ & \multicolumn{2}{|l|}{ Dipan \& Pachana } & \multicolumn{4}{|c|}{ Arogyavardhini Vati 1 BD. } & \multicolumn{2}{|c|}{10 days } \\
\hline $\begin{array}{l}05 / 12 / 14- \\
08 / 12 / 14\end{array}$ & \multicolumn{2}{|l|}{ Snehapana } & \multicolumn{4}{|c|}{$\begin{array}{l}\text { With Phala ghruta (as per kostha \& agni) in in- } \\
\text { creasing dose. Average initial dose was } 30 \mathrm{ml} \text { and } \\
\text { maximum dose was } 130 \mathrm{ml} .\end{array}$} & \multicolumn{2}{|l|}{4 days } \\
\hline \multicolumn{9}{|c|}{ Detail of Snehapana } \\
\hline Date & Snehapana & \multicolumn{2}{|c|}{ Time } & Matra & Snehajirna kala & \multicolumn{2}{|c|}{ Snehajirna Avadhi. } & Lakshana \\
\hline $05 / 12 / 14$ & Phala ghrita & \multicolumn{2}{|c|}{ 8:00 am } & $30 \mathrm{ml}$ & $11 \mathrm{am}$ & \multicolumn{2}{|l|}{$3 \mathrm{hrs}}$. & NAD \\
\hline $06 / 12 / 14$ & Phala ghrita & \multicolumn{2}{|c|}{ 8:00 am } & $60 \mathrm{ml}$ & $12 \mathrm{am}$ & \multicolumn{2}{|l|}{$4 \mathrm{hrs}$. } & NAD \\
\hline $07 / 12 / 14$ & Phala ghrita & \multicolumn{2}{|c|}{$8: 00 \mathrm{am}$} & $100 \mathrm{ml}$ & $05 \mathrm{pm}$ & \multicolumn{2}{|l|}{$8.5 \mathrm{hrs}$} & NAD \\
\hline $08 / 12 / 14$ & Phala ghrita & \multicolumn{2}{|c|}{$8: 00 \mathrm{am}$} & $130 \mathrm{ml}$ & $8.45 \mathrm{pm}$ & \multicolumn{2}{|l|}{12 hrs. } & $\begin{array}{l}\text { Shiroshul, Dour- } \\
\text { balya. }\end{array}$ \\
\hline $09 / 12 / 14$ & \multicolumn{8}{|l|}{ Sneha Viram } \\
\hline $\begin{array}{l}10 / 12 / 14- \\
12 / 12 / 14\end{array}$ & \multicolumn{2}{|c|}{$\begin{array}{l}\text { Abhyanga \& Bashpa } \\
\text { swedan }\end{array}$} & \multicolumn{3}{|c|}{$\begin{array}{l}\text { Kshirbala Tail \& Dashmoola kwath } \\
\text { bashpa peti sweda. }\end{array}$} & \multicolumn{3}{|l|}{3 days. } \\
\hline $12 / 12 / 14$ & \multicolumn{2}{|c|}{ Virechana karma } & \multicolumn{3}{|c|}{ Trivrutt avaleha $20 \mathrm{gm}}$. & & & \\
\hline \multicolumn{9}{|c|}{ Total no. of Vegas 11, No virechana vyapads are seen. } \\
\hline $12 / 12 / 14$ & \multicolumn{2}{|l|}{ Samsarjana Kram } & \multicolumn{3}{|c|}{$\begin{array}{l}\text { Regulatory diet regimen as per Sud- } \\
\text { dhi. }\end{array}$} & \multicolumn{3}{|c|}{4 days Samsarjana kram advice. } \\
\hline
\end{tabular}

Table 3: Details of Vamana Karma

\begin{tabular}{|c|c|c|c|c|c|c|}
\hline Date & Procedure & \multicolumn{4}{|l|}{ Drug \& Dosage } & Duration \\
\hline $20 / 03 / 15$ & Dipan \& Pachana & \multicolumn{4}{|c|}{ Agnitundi Vati 1BD } & 2 days. \\
\hline $23 / 03 / 15-25 / 03 / 15$ & Snehapana & \multicolumn{4}{|c|}{$\begin{array}{l}\text { Kalyanak Ghrita (as per kostha \& agni) in increasing dose. } \\
\text { Average initial dose was } 30 \mathrm{ml} \text { and maximum dose was } 90 \mathrm{ml} \text {. }\end{array}$} & 3 days. \\
\hline \multicolumn{7}{|c|}{ Detail of Snehapana } \\
\hline Date & Snehapana & Time & Matra & Jirnakala & Avadhi, & Lakshana \\
\hline $23 / 03 / 15$ & Kalyanak Ghrita & $7.45 \mathrm{am}$ & $30 \mathrm{ml}$ & $12.45 \mathrm{pm}$ & $5 \mathrm{hrs}$. & \\
\hline $24 / 03 / 15$ & Kalyanak Ghrita & $7.45 \mathrm{am}$ & $60 \mathrm{ml}$ & $04.15 \mathrm{pm}$ & $9 \mathrm{hrs}$. & Kshudha \\
\hline $25 / 03 / 15$ & \multicolumn{2}{|l|}{ Kalyanak Ghrita } & $90 \mathrm{ml}$ & $10.30 \mathrm{pm}$ & $14 \mathrm{hrs}$. & Kshudha \\
\hline $26 / 03 / 15$ & \multicolumn{2}{|c|}{ Abhyanga \& Bashpa swedan } & \multicolumn{2}{|c|}{$\begin{array}{l}\text { Sarvang abhyang with Dhan- } \\
\text { vantar tail f/b mrudu bashpa } \\
\text { peti sweda. }\end{array}$} & \multicolumn{2}{|l|}{1 day. } \\
\hline $27 / 03 / 15$ & \multicolumn{2}{|l|}{ Vaman Karma } & \multicolumn{2}{|c|}{$\begin{array}{l}\text { Madan phala pippali-5gm } \\
\text { Vacha-3 gm } \\
\text { Saindhav-2 gm }\end{array}$} & \multicolumn{2}{|c|}{$\begin{array}{l}\text { Given at } 7.25 \text { am on empty } \\
\text { stomach. }\end{array}$} \\
\hline
\end{tabular}




\begin{tabular}{|l|l|l|l|}
\hline \multicolumn{2}{|l|}{} & \multicolumn{2}{|l|}{ Madhu-Q.S } \\
\hline Vaman Assessment & \multicolumn{2}{l|}{} \\
\hline Antiki & Pittant & \\
\hline Vaigiki & 3 Vega, 3 Upvega & Regulatory diet regimen as per Sud- & 3 days. \\
\hline Maniki & Input 1.8 lit. Output 2 lit. & dhi. \\
\hline Vaman Sidhhi & Avar & \\
\hline $27 / 03 / 15-29 / 03 / 15$ & Samsarjana Kram &
\end{tabular}

\section{Source of Support: Nil}

\section{Conflict of Interest: None Declared}

How to cite this URL: Shruti R. Tarapure et al: Management of Granthibhuta Aartava Dushti w.s.r. To PCOD - A Case Report. International Ayurvedic Medical Journal \{online\} 2020 \{cited November, 2020\} Available from: http://www.iamj.in/posts/images/upload/2625_2631.pdf 